\title{
Climate-Change Blues: Sustaining Village Life in Tonga
}

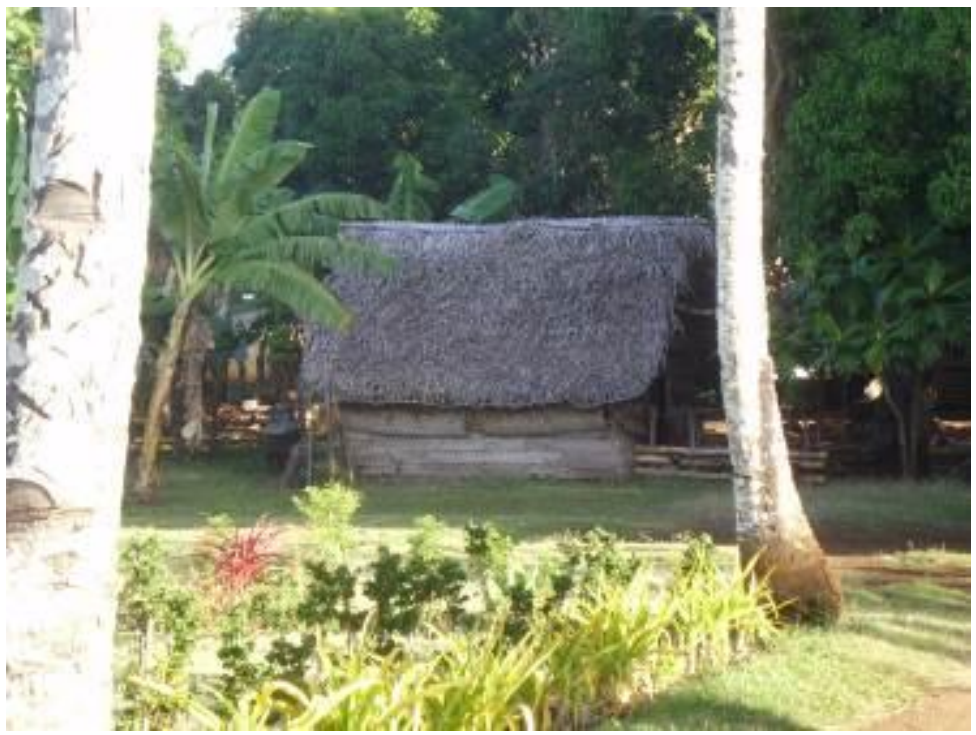

\section{Abstract}

The loss of small island states will affect us all. Climate change refugees will become a very serious issue for all countries.

Lord Ma'afu

Teena Brown Pulu has a PhD in anthropology from the University of Waikato. She is a senior lecturer in Pacific development at AUT University. Her first book was published in 2011, Shoot the Messenger: The report on the Nuku'alofa reconstruction project and why the Government of Tonga dumped it. 
On the afternoon of December 15th 2009, Tonga's Minister for Environment and Climate Change, Lord Ma'afu, made a passionate plea to the international press assembled at the 15th United Nations Climate Change Conference in Copenhagen, Denmark. He had a message he wanted to get out to the world. Politically, Ma'afu awoke a subconscious fear developed countries stepped around not wanting to stir and be forced to deal with. Snared in the small island uncertainty of rising sea levels was the inevitability climate change refugees might need another place to live (Bedford and Bedford, 2010; Fagan, 2013). Where would they go? Who would take them in? What countries would help the Pacific Islands?

Despite sociologists and political scientists documenting the failure of global governance to deliver a legally binding agreement for controlling climate change (Giddens, 2009; Held and Hervey, 2009; Fisher, 2004), alternatives put forward have not been taken up. What other methods for governing over bad weather are there? (Goldin, 2013). And how is village life in Tonga coping with climate blues?

\section{Our land, our home}

The best people possess a feeling for beauty, the courage to take risks, the discipline to tell the truth, the capacity for sacrifice. Ironically, their virtues make them vulnerable; they are often wounded, sometimes destroyed.

\section{Ernest Hemingway}

Ma'afu's sentiments were purposeful. He silenced the room. Addressing a press conference on Sinking Islands, The Pacific Voice, his words held listeners close as if he was whispering something so gravely serious he could only utter it once. 
Our land is precious for us. It is our home. It is owned by our fathers and grandfathers, and we do not want to leave it; especially because change is something we did not cause. We want to continue to pass it on to our children and grandchildren.

Lord Ma'afu

Marianne de Nazareth, an environmental reporter from Goa wrote Ma'afu spoke emotionally (de Nazareth, 2009), quite unexpected for a government minister, especially a noble of Tonga's ruling class disciplined to maintain "role distance in conversations" with ordinary people (Marcus, 1980, p. 435). But under pressure to get a win for his country, his ocean region, his part of the world, and with hope disappearing the big country polluters would assent to reducing carbon emissions, he put it out there unpretentiously and without airs. He wore no camouflage, which was extraordinary for a politician at a United Nations talkfest to strip down to their vulnerability. This is what struck people and stuck in their memory. His naked truth both haunted and lured them.

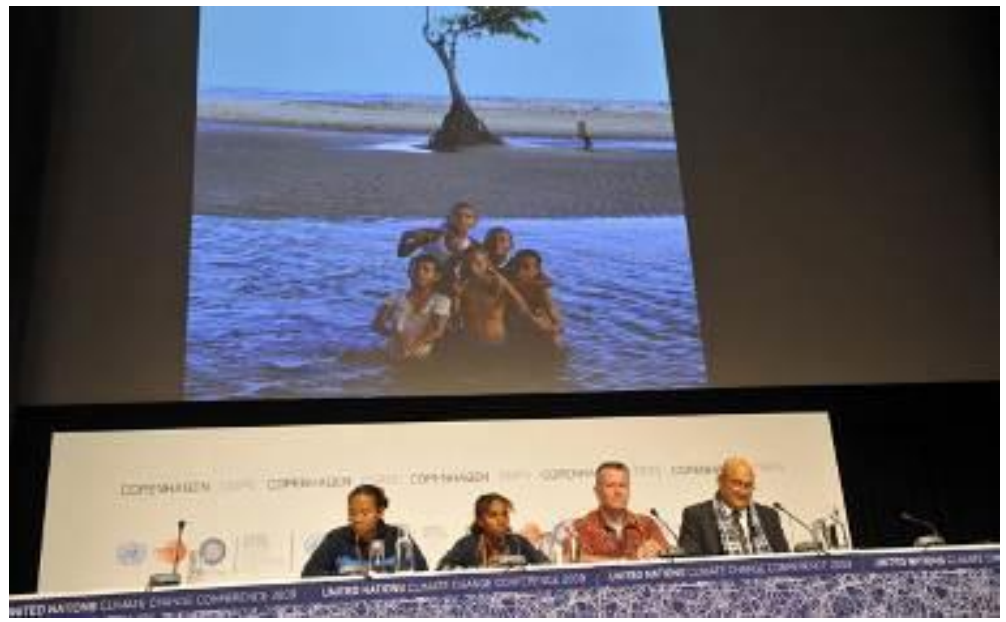

Press Conference on Sinking Islands, The Pacific Voice, at the 15th United Nations Conference on Climate Change, 
Copenhagen, Denmark, 15 December 2009: Rebecca Asigau, youth representative of Papua New Guinea; Maylin Sese, youth representative of the Solomon Islands; Espen Ronneberg, climate change advisor to the South Pacific Regional Environment Programme (SPREP); Lord Ma'afu, Tonga Minister for Environment and Climate Change. (Photograph: The Guardian, 2009).

At the 15th United Nations Conference on Climate Change in Copenhagen, Denmark, on December 15th 2009, it was not what Tonga's Minister for Environment and Climate Change, Lord Ma'afu, said to a press conference that won him notoriety with mostly European journalists. It was the way he delivered. Eyes down, the bond to his people at home broke his concentration on reading a script word-for-word, letting the audience know he was battling to contain emotion, fighting back tears for his country. The place closest to his heart he did not want to lose to cyclone and rising sea was the very manifestation of sinking islands he was thinking of.

Curtis Doebbler, law professor at An-Najah National University in Palestine co-authored a cutting commentary stating what the poorest countries in the world undergoing the greatest deterioration from climate change had inherited from the richer ones: "In the end, selfishness and greed triumphed as the legacy of Copenhagen" (Doebbler and Wewerinke, 2009). Doebbler echoed the widespread indignity that people felt coming away without an accord in hand.

A week of "just arguments" put on the negotiations table had not resulted in a legally binding agreement to reduce carbon emissions. And this triggered a power imbalance that was agonisingly painful for developing countries that were present and accounted for, observant and focused, but not counted in the final decision. The tale unfolded that America and a cluster of big polluter states blocked the doorway to reaching consensus on how immediate climate action would 
be taken. Understandably Doebbler vented his frustration, giving reason to his rage.

In the end it was not the logic of science or the integrity of just arguments that prevailed, but rather the brute force of political and economic power that forced an outcome that threatens the planet that the indigenous peoples call Mother Earth. The calls of indigenous leader and Bolivian President Evo Morales to ensure global warming would not exceed 1.5 degree Celsius fell on deaf ears. The plea by Reverend Desmond Tutu that "no agreement is better than a bad agreement" was ignored. The impassioned logic of Ambassador Lumumba Di-Aping to act in the interest of all the people on earth and not just a selected few elites went unheeded. (Doebbler and Wewerinke, 2009).

\section{Global governance passed away}

In Ma'afu's case, he had breathed in enough toxicity from the political atmosphere, exhaling with greater conviction that climate "change is something we did not cause." His logic propelled the climate case of Pacific Island states; that is, we are forced by the powerful to suffer the ill-fated consequences of having their greenhouse gasses invade our ocean, the caregiver for small islands and her peoples (Paton, 2009). The sea mother had turned rabid and was rising, eating her own.

Four years ago there was an undercurrent to Ma'afu's declaration which foretold the dilemma faced today (Gibson, 2010). Not singly were the seventeen Pacific countries affiliated to the Alliance of Small Island States (AOSIS) on global climate change not the cause of climate change (Uludong, 2013), neither did they instigate world governance, the United Nations structure and process for getting member states to come to a consensus on climate action. As Doebbler pointed out, the negotiations method favoured "a selected few 
elites" and by no means acted "in the interest of all the people on earth."

But if the system was inequitable the question which surfaced was why were political leaders, especially leaders of poor countries, still investing faith in world governance to provide a fair solution to their predicament? It did not make sense, but then The Politics of Climate Change (Giddens, 2009) were not entirely rational, reasonable, and realistic. Environmental scientist, Jerald Schnoor raised the human disaster warning that climate change researchers and journalists were grappling to cope with: "What if the process to negotiate an international climate treaty is completely broken?" (Schnoor, 2010).

Schnoor mapped out the hard-bitten reality. He validated how the 15th United Nations Climate Change Conference failed to deliver a comprehensive arrangement which could be sustainably practiced for the next ten to forty years (De Mesquita, 2009). In context, the United Nations principles which measured "a final agreement" were that an accord had to be "fair, ambitious, and binding" (Schnoor, 2010). Clearly the Copenhagen deliberations achieved none of these.

COP15 fell far short of its goals. It did not establish emission reduction targets for developed countries, either short (2020) or long-term (2050); it did not set a deadline for a binding treaty; and it did not pass the policy most clearly supported by all 193 countries, Reducing Emissions from Deforestation and Forest Degradation (REDD). Of the three criteria for a final agreement: Fair, Ambitious, and Binding (FAB), the Copenhagen Accord failed on all three accounts. The poorest nations do not believe it is fair; the European Union (EU) and climate scientists would certainly not characterize it as ambitious; and the Copenhagen Accord that emerged is not binding. (Schnoor, 2010). 
From Schnoor's description of events, the sharpened point about "broken process" had gotten wedged in critical thought (Schnoor, 2010). Here was the model argument that wedded democracy and global governance in a long-term commitment to climate change (Fisher, 2004). In this sense, because global governance had failed to deliver a legal framework managing climate change internationally, or rather, controlling the biggest polluters by an international system of fines and penalties, theories were fuelled as to how climate action could hold world powers to account. The reality was world powers doubled up as world polluters, the United States of America and Asia's fast-developing economies of China and India.

Public policy researchers David Held and Angus Hervey emphasised the relationship key was mobilising "state level solutions" as the method of political bargaining power at the "global governance level" (Held and Hervey, 2009, p. 2). In terms of public policy, Held and Hervey argued the opposite scenario had taken hold.

At global governance level there has so far been a failure to generate a sound and effective international framework for managing global climate change, whilst at state level solutions are weak and struggle to transcend the normal push and pull of partisan politics. (Held and Hervey, 2009, p. 2).

Underpinning the authors' theory was the notion that if "state level solutions" were robust as opposed to weak, national policy could pressure and manipulate "global governance" into climate action. In actual fact, Held and Hervey were responding to what Idso, Carter, and Singer had described in one short sentence: "But one thing is certain: The Kyoto Protocol is dead" (Idso, Carter, and Singer, 2011, p. vi). If global governance had passed away, then another course of action was for national laws, regulations, and policies to make climate adaptation the state's foremost priority, and for the 
nation-state to collaborate regionally and internationally for climate justice. In their introduction to a United Nations commissioned report on Climate Change Reconsidered by a panel of nongovernmental organisations, Idso, Carter, and Singer made it painstakingly clear that the Kyoto Protocol 1997 was terminally defunct (Idso, Carter, and Singer, 2011, p. vi).

This mandated agreement originally assented to by 192 parties formed the United Nations Climate Change Convention Framework (UNCCCF) from 2005 to 2012 on reducing carbon emissions for developed countries. Developing countries, by comparison, were expected to voluntarily reduce emissions by steering away from fossil fuels and adopting renewable energy. But post 2012 the world was without a legally binding agreement which the UNCCCF could act on with majority support from member states. Powerful countries had broken away from post 2012 emissions' targets largely because the United Nations looked as if it would endorse that developing countries with legitimate claims for environmental loss and damage should receive compensation (Lipset, 2013).

China, categorised as a developing country, emitted $14 \%$ of the world's greenhouse gases. The catch was its developing country status meant that although China was an emerging economy on the global stage, it was not legally obliged to an international agreement. Exacerbating political tension was Japan, New Zealand, Russia, Canada, and the USA, the developed countries that refused to take on a new legally binding framework put forward at the United Nations climate change conferences. What came after the expiry of Kyoto? (Bodansky, 2009).

\section{Pacific states, Pacific region}

In the South Pacific region, Pacific Island states were pursuing a two-fold climate strategy of strengthening national policy and regional cooperation. The difficulty, as the Cook Islands 
Minister of Finance Mark Brown explained, was working through the complex maze of "bilateral, regional, and multilateral" agreements to meet all compliances for "accessing funds." In July of 2013 at the first joint meeting for the Pacific platform for disaster risk management and the Pacific climate change roundtable convened in Fiji, Brown highlighted the frustration of "funds not getting into the country for project activities." His rationale was that "regional organisations" were useful in the sense they could manoeuvre their "relationships with development partners" to unlock funding for Pacific Island states (Komai, 2013a; Radio New Zealand, 2013a).

We have difficulties accessing these funds because of the different requirements at the bilateral, regional and multilateral level. These funds are not getting into the country for project activities. This is where we will need the support of regional organisations, who can use their networks and relationships with development partners to access these funding mechanisms. (Mark Brown cited in Komai, 2013a).

Sefanaia Nawadra contextualised Mark Brown's discussion. Nawadra, the director of the environmental monitoring and governance (EMG) division at the Secretariat for the Pacific Regional Environment Programme (SPREP), succinctly described the funding predicament for Pacific Island states.

Many of our small island countries struggle to deal with the multitude of international agreements, policy commitments and related implementation and reporting requirements. (Sefanaia Nawadra cited in Komai, 2013b). 
A barrage of bureaucratic red-tape and "reporting requirements" made the funding flow from First World donor to Third World recipient a complicated, cumbersome procedure (Perrottet, 2013). Nawadra implied the "struggle to deal with the multitude of international agreements" did not hinge individually on capacity building and re-training bureaucrats in small island developing states to comply with the demands of international agencies (Komai, 2013b). There were big picture problems, compounded by an underlying strain in that international agreements took place in different systematic arrangements from country to country, regionally between countries, and multilaterally between regions. What was agreed to, more often than not, collided and cancelled each other out at various levels of geo-political influence.

In Tonga's case, strengthening country to country ties with the People's Republic of China triggered tension and suspicion from New Zealand, the traditional development partner. For the newly formed Pacific Islands Development Forum (PIDF) led by the Republic of Fiji, its very inception stirred unease and nervousness with the conventional Pacific Islands Forum dominated by Australia and New Zealand. The worry was whether the Fiji-led inter-government alliance would contest, challenge, and eventually eclipse the regional polity leadership and power-base of Australia and New Zealand.

Lastly on the international stage, Tonga's Minister for Finance Lisiate 'Akolo clarified that national strategies for climate adaptation such as accelerating renewable energy sources had the potential to conflict with policy conditions setdown by the inter-government organisations of developed countries. On this point, 'Akolo described an incident that occurred in which European Union (EU) funding was withheld from the Tonga Energy Road Map (TERM).

[Tonga Minister for Finance Lisiate 'Akolo] said that under Policy Metric there was a list of things for government to do before budget support is released. 
Under the current budget because the Tonga Energy Road Map (TERM) had failed to fulfil the EU requirement, they did not release their budget support. (Matangi Tonga, 2013b).

The former Prime Minister of Papua New Guinea, Mekere Morauta, called out the development dilemma in moving regional polity forward for Pacific Island states. As the chair of the team conducting the second Pacific Plan Review 2013, Morauta's criticism was candid. The Pacific Plan for Regional Integration and Cooperation 2005 was "the master strategy" directing the 15 member countries of the Pacific Islands Forum in how inter-government polity among the South Pacific states led by Australia and New Zealand, was carried out (Pacific Plan Review, 2013).

In his preliminary comments on the review process, Morauta bluntly stated "the rules of the game are wrong" (Morauta, 2013). Expressing that he thought "governance structures" did not deliver what was pledged in policies, plans, and strategies, he saw that funding to small island developing states defined what they got. Subsequently, the rules of overseas funders disallowed Pacific Island states to make development decisions according to their own "political values" and community needs (Morauta, 2013).

The institutions - the 'rules of the game' - are wrong, or perhaps have gradually been weakened by, on the one hand, governance structures that don't ensure the right outcomes, and on the other hand incentives - usually financing incentives - that serve to shape the agenda more than does the exercise of political values and choice. (Morauta, 2013). 


\section{The people are not happy Natives}

In Tonga, the Tu'ivakano government floated a political desire for the state to foster closer working relations with communities to make climate adaptation happen. Tonga's first government after the 2010 democratic reform decided in 2013, its third year of four in office, to brand the administration to resemble the climate campaigners. What the government's aspiration came down to by way of community development that did not rely on state financing and aid assistance was never revealed in official statements and national policy. One factor was sure; the government budget was heavily dependent on aid donations and bank grants which were not at all guaranteed as an absolute donedeal because the final decision belonged to the money-giver not the developing country recipient.

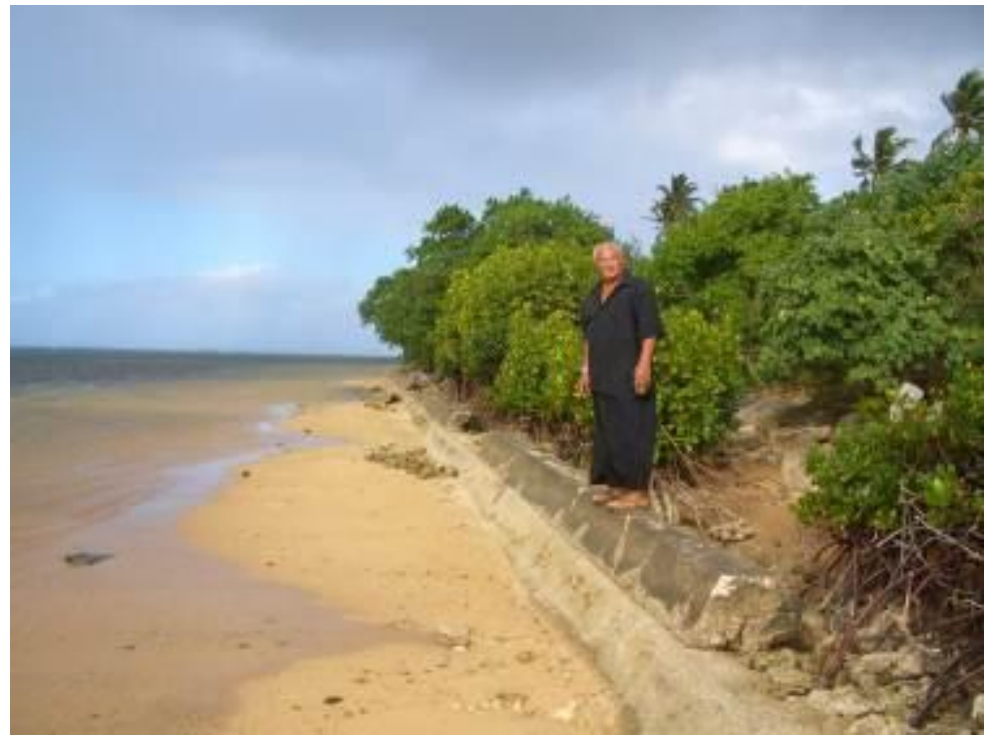

Lord Nuku, noble and estate-holder of Kolonga in the eastern district of Tonga, standing on the seawall fronting Kolonga foreshore and coral reef which is used by villagers for inshore fisheries. Depletion of stock 


\section{compounded by rising sea levels is a conservation and sustainable food supply priority.}

The Government of Tonga did not have the capacity or reach to bankroll climate mitigation projects that village communities across the country wanted in their territorial confines. People in the village knew that the talk of international funding for climate adaptation in small island developing states was illusive. It was understood as pie-inthe-sky political rhetoric, meaning the much coveted funding was out-of-reach for villagers living and suffering silently on the ground.

The notion that ordinary Tongans were suffering in silence manifested for two weeks in July of 2013 when Television Tonga News aired evening segments on the parliamentary visits of the peoples' representatives to constituencies. Overall, meetings were not well attended with what appeared to be an average of less than 20 adults at various villages contributing dialogue on development issues impacting on their communities. Young adults were not visible. The meetings were dominated by middle-aged to elderly men. Most notably, however, only some villages from the largest island of Tongatapu featured in the news items, illustrating the privilege of being located on the mainland in contrast to living on an outer island, the peripheral edge of Tonga given less development priority.

Significantly, gatherings were not solutions oriented but forums for people to air concerns, disgruntlement with the government's lack of action, and at times, long-running grievances. A standard line the people's representatives to parliament fed to registered voters in attendance was that selected discussion points would be raised in reports to the House. The final decision on what got reported and what was left out was made by the parliamentarians not the people because a democratic vote at constituency meetings on the top priorities of communities did not eventuate. 
The facial expressions and body language of men and women gathered in church and community halls for the parliamentary visits showed despondency and disenchantment. Television cameras scanned audiences of grimaces, scowls, and arms folded in defiance, gesturing that the political scenario of not having matters resolved had been seen and heard before. By this, failing to take action on community interests was a repeat episode of the Tongan state's method for dealing with constituencies before the 2010 democratic reform. People were fed up with authoritarian, high-handed, patronising, and full-of-advice parliamentarians telling them the issues would be reported, recorded, and filed with the bureaucracy. Politically in terms of power sharing and participatory democracy, what had changed?

Surprisingly it was 'Akilisi Pohiva, the leader of the Democratic Party of the Friendly Islands which was the opposition in the House, who had changed his tune by modifying his traditional practice of anti-government politics. Pohiva in the present had done a turn-around and was now backing the state and the church as Tonga's bedrock of authority and social control over the people. Sixteen years ago in 1997 Pohiva had a different story about the Government of Tonga which he shared with David Robie, a journalism academic filming a documentary on media freedom in South Pacific states.

Tonga is not a democratic country. The most vital element of a democratic government is accountability. There is a complete lack of accountability that causes corruptions, misuse of the resources, and other evils in the country. (Robie, 1997).

In 2013, Pohiva's message to his constituency Tongatapu 1 was that the "evils in the country" were no longer attributed to the government (Robie, 1997). Put simply, the development miseries of Tonga's villages were not entirely the government of 
the day's fault. Rather, the amount of community development projects the Tongan state could commit to depended on the amount of funds allocated in the national budget.

Tongatapu number one representative says that all the issues of concern have been recorded and will be submitted to the House, and the rest will be discussed by Kolomotu'a town council. In the meantime, he highlights that the implementation of these works is very much depending on the government's revenue. (Television Tonga News, 2013a).

Pohiva gave strong advice to his constituency to "work together with the government and the church." It was a "must" that the people cooperated with the authorities of a small island power structure to avoid dissent and disagreement (Television Tonga News, 2013b).

Meanwhile the parliamentarian of the constituency told the meeting, that it's the government's role to monitor and take care of its development activities. Pohiva also advised the meeting that in order to achieve their needs the people must work together with the government and the church. (Television Tonga News, 2013b).

What became perceptible from Pohiva's political instruction to voters in his electorate is that Tonga's longest running people's representative of twenty six years had an official line to deliver. In context, it was not that Pohiva did not hear what the audience brought up during his parliamentary visit. Instead, he elected to push the official line that state compliance and church conformity corresponded with political and economic development for Tongan communities. This was a far cry from the Pohiva of 
old arguing that Tonga was "not a democratic country" and the government is not accountable to the people, but a law unto itself (Robie, 1997).

The query that emerged was why had the leader of the Democratic Party changed his strategy in mid-stream? Moving towards an election year in 2014, Pohiva's unwillingness to explain his pro-government position aroused suspicion among voters. In the social climate of democratic reform, for a parliamentarian to order his constituency to obey the state bureaucracy and the church without question or qualm did not, by any means, convey transparent communication. What were the reasons for the Member of Parliament's call to such action?

Pohiva's political metamorphosis was viewed with scepticism. Customarily, he expressed anti-government policies. His defiance against the Tongan state as an opposition leader had won him notoriety with, and support from, international media and sympathisers. But as a career politician, what did he stand to gain from throwing his lot in with the establishment? Were Pohiva's sights still set on becoming the elected Prime Minister in 2014 at 70+ years old? If so, then perhaps his transition towards state and church loyalty reflected how he would quell public criticism if elected to office.

Nukunuku, the principal village on the estate of the noble Prime Minister Lord Tu'ivakano with a population of 1,781 gathered an audience of around twenty adults for the parliamentary visit of people's representative for Tongatapu 5, 'Aisake Eke (Maron and Connell, 2008). Eke was an independent member of parliament. However, in July 2013 he demonstrated support for 'Akilisi Pohiva's Democratic Party by signing off a parliamentary bill submitted by the party. The bill proposed that Tongan citizens registered on the general electoral roll elect the prime minister (Kaniva Pacific, 2013). Under Tonga's political structure which was reformed in 2010, 
the prime minister was elected by parliament not the registered voters.

This was the second incident in Eke's 2010 to 2014 history as the Tongatapu 5 member of parliament that his political will split public opinion within Nukunuku. The first was his backing of the motion for a vote of no confidence in the Prime Minister Lord Tu'ivakano put forward in the House on June 28th 2012 by 'Akilisi Pohiva and the Democratic Party. Nukunuku, the village at the heart of the Prime Minister's estate was fractured in two, where some endorsed Eke and the Democratic Party's latest bill, while others objected. The reality was there appeared to be more people living on the Noble Tu'ivakano's estate, which encompassed four villages, who opposed. Thus, the obvious way to show disagreement with Eke's politics was by not attending his parliamentary visit.

An independent member of parliament's role and responsibility provided the frame and focus for questioning Eke's political strategies. His actions put him in direct opposition with the Prime Minister, who was the estate-holder for his constituency. However, this did not necessarily shape the dispute from which criticism surfaced. People probed how politically independent he was, given that Eke aligned himself closely with the Democratic Party instead of voting in parliament the way in which the majority of his constituency wanted. Unveiled were divergent ideas of democracy. While Eke advocated that a prime minister elected by registered voters would engineer greater public accountability, his own constituency reconsidered how they could hold their member of parliament accountable to ensure his vote on bills and debates in the House corresponded with their public interests. 


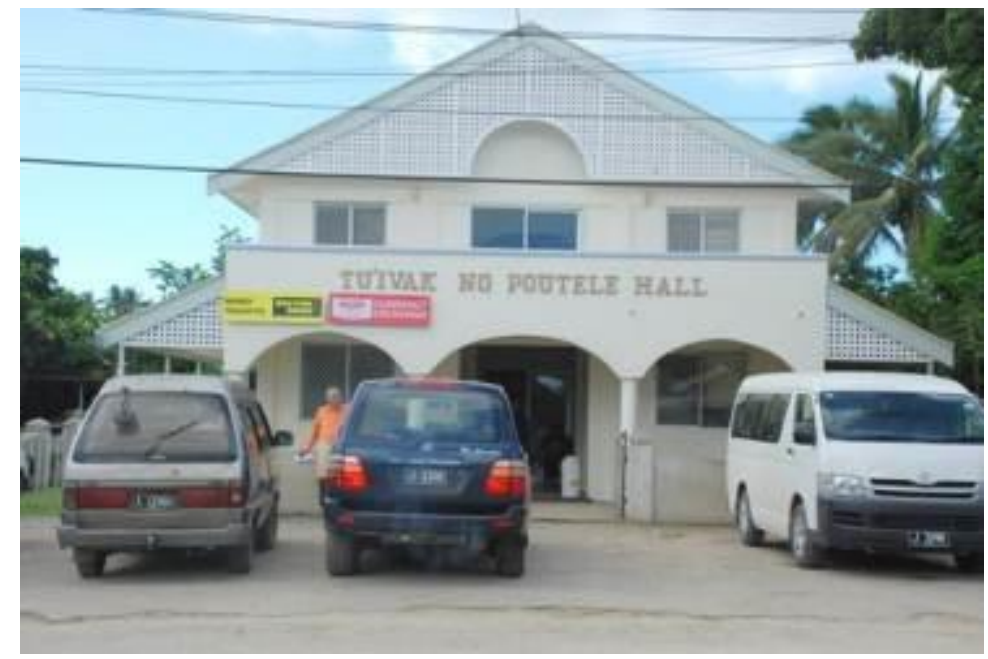

Tu'ivakano Poutele Hall where the parliamentary visit was held for the people's representative of Tongatapu 5, 'Aisake Eke. Tu'ivakano Poutele Hall is located in the centre of Nukunuku, the principal village on the estate of the noble Prime Minister Lord Tu'ivakano.

During Eke's annual parliamentary visit, the Nukunuku town officer commented that rising sea levels had caused "soil erosion" and the loss of two acres of land in western district (Television Tonga News, 2013a). This, he thought, was the pressing matter for the village. The climate fear was that given the rate of land loss, could village life be sustained, and for how long until relocation was the only option for survival on a coral atoll? The town officer asked if a foreshore could be constructed as a measure of resilience for keeping back "the hungry tide" (Zubrycki, 2011).

Meanwhile, [Nukunuku] town officer Matafonua requested whether they can build a foreshore to combat soil erosion in the western district. He told the gathering that impacts on climate change causes 
erosion to two acres of land in the area. (Television Tonga News, 2013a).

\section{Top-down policy trap}

The "request" exposed that government policy flunked at integrating community development into its practical application (Television Tonga News, 2013a). Marginal coordination was transacted between national strategies for climate adaptation, and projects that villages desired, such as the Nukunuku town officer's proposal to build foreshore resilience in western district. Two conversations about climate change were gaining traction in Tonga, but oddly, the participant groups were not in partnership or working alongside each other. Primary discussions took place among state bureaucrats pushing to make Tonga the first Pacific Island country to implement a national climate change plan bankrolled by the United Nations Development Programme Global Environment Facility (UNDP-GEF). Conversely, peripheral dialogue came from village communities, who oncea-year were given a chance to list development priorities and goals for the visiting member of parliament to report back to the House.

Structurally, there were two gaping cracks preventing any systematic cohesion between the climate talk from above, and the murmurs from below. Firstly, the Tongan state did not possess nor practice a national policy framework integrating all sectors under a climate adaptation plan. This was still in the pipeline and the logic of designing one was top-down, driven by the availability of international funding and the results that funders demanded, rather than the communities' self-determined needs and aspirations.

An interview with Television Tonga News saw the "national coordinator for Tonga's climate change" plan call for ordinary Tongan citizens - the key stakeholders in the country's 
adaptation - to be involved in high-level discussions with the state bureaucracy (Television Tonga News, 2013d).

A national coordinator for Tonga's climate change project says the workshop was held in Nuku'alofa to educate stakeholders on the issue. It also highlights the need for people to join in national discussions so they are aware of the effects of climate change. (Television Tonga News, 2013d).

By no means was the national coordinator suggesting that communities were to contribute to the national plan's design and how it would be carried out in villages and districts. Conversely, he was insinuating that raising public awareness on what the government was doing, provided the method for getting community agreement that the state bureaucracy is the national controller over what would, and would not, get done. National climate action was delivered on a shoe-string budget dependent on overseas aid, regional organisations, and United Nations (UN) funding. In a coconut shell, the state was the gatekeeper in charge.

The novel idea that village communities had local knowhow, teamwork, and resources to plan and put into action climate projects did not altogether register with the machinery of government. Moving forward from an obsolete public servant mentality, one in which it was believed the state bureaucracy knew what was best for the people and would do what it wanted regardless of what citizens thought, proved difficult. In Tonga, the government sector grappled to practice structural reform and organisational change to build an inclusive society grounded in participatory democracy.

Secondly, the Tongan state adhered to the advice of Margareta Wahlstrom, the Special Representative of the Secretary General for the United Nations Office for Disaster Risk Reduction (UNISDR) based in Geneva, Switzerland. En route to address the inaugural joint meeting of the Pacific 
Platform for Disaster Risk Management and Pacific Climate Change Roundtable forum in Fiji from July 8th to the 11th, she stopped over in Tonga. At a quasi-public meeting that appealed more to bureaucrats than people who were not employed by the government, Wahlstrom took it upon herself and her position of power to define what "ordinary citizens should be concerned" about in the Kingdom of Tonga (Folau, 2013).

Ordinary citizens should be concerned because you live in an environment where you can anticipate there would be another cyclone for earthquake and you can lose your personal belongings, or your production like a farmer loses his harvest. In addition, very few people have insurance or any financial buffer let alone the risk of losing healthcare and education time if schools are closed, or you even lose a member of your family." (Margareta Wahlstrom cited in Folau, 2013).

Laced in the speech-making was the top-down policy trap of deficit theory; that is, the argument that "ordinary citizens" of developing countries were at greater risk of losing lives and livelihoods because they were financially ill-prepared for loss and damage. However, the Western-centric idea that loss and damage caused by natural disaster could be moderated by insurance, failed to understand ordinary lives in small island developing states. By what means was it possible for poor people to have the financial capability to insure "personal belongings" and property, particularly in Tonga, where traditional land tenure meant that "ordinary citizens" not of the landed gentry leased, but did not out rightly own, land? (Folau, 2013a).

Despite being situated at odds with Western economic liberalism in which citizens safeguarded their ownership over private property by purchasing insurance, the Government of Tonga followed suit. In the process of amalgamating disaster 
management with climate adaptation, the Tongan state was crafting a unitary national framework. Refocusing the country on the double risk of natural disaster exacerbated by climate change was viewed as the only course of policy action, not singly for Tonga but the South Pacific region. In saying this, no locally devised measures integrating traditional knowledge were explored or considered worthwhile because the United Nations Office for Disaster Risk Reduction was perceived to have direct access to the purse strings, and consequently, defined the rules.

Sitiveni Halapua, the deputy leader of the Democratic Party of the Friendly Islands, spoke about integrating "indigenous knowledge" into Pacific Islands' climate adaptation. He thought traditional knowledge had been lost in Tonga, disappearing during his "lifetime" (Halapua, 2012). Chairing a panel in April of 2012 on indigenous knowledge at a University of Hawai'i conference for climate change in the Pacific Islands, Halapua opened the discussion with a "personal reflection" from his childhood years in Tonga (Halapua, 2012).

Let me give you a personal reflection on the issue of particularly indigenous knowledge. One of the advantage of just aging quickly, like myself, I was quite amazed at how much indigenous knowledge we lost, say, even in my home country Tonga during my lifetime. What I had learned when I was a small boy growing up and going to the family subsistence garden about food security, how to harvest and leave some food in case there's a drought or other natural disaster and stuff like that, it's completely gone; I mean, during my lifetime. I just thinking aloud to myself now whether the right place for indigenous knowledge is the classroom or the community; do we have enough? (Halapua, 2012). 
Halapua posed a pertinent question: Where was the appropriate place to reinvent tradition in Tonga? Given that he saw "indigenous knowledge" had been abandoned to modernity, he queried whether it was "the classroom or the community" which offered the most accessible learning context for resurrecting "food security" in the 21 st century through "subsistence" gardening (Halapua, 2012).

Contrariwise, the Government of Tonga's single-minded approach revolved around an illusive pool of international funds existing in the opaque language of United Nations' officials. As long as high-powered bureaucrats like Margareta Wahlstrom alluded to money being made available for developing states that conformed to the UN agenda, disaster management and climate change sang a harmonious duet. Given the pressure to comply and toe the line, how could Tonga and other small island developing states not cling to hope that there really was a pot of gold at the end of the adaptation rainbow?

The Australian Government's Department of Industry, Innovation, Climate Change, Science, Research and Tertiary Education ran the Pacific Adaptation Strategy Assistance Programme (PASAP) for 15 partner countries which were Pacific Island states (Australian Government, 2013; Chung, 2013; Coutts, 2013b). Fuka Kitekei'aho, Tonga's national coordinator for PASAP, brought to light the rationale of conflating disaster management and climate change.

Slowly it seems the livelihood of the people, and that's quite an impact the coastal erosion affect the livelihood of the people. And now there's hardly anybody fishing so the livelihood now for the women has been derived from weaving mats. (Fuka Kitekei'aho cited in Coutts, 2013b).

In a coconut shell, disaster management coupled with climate change sprang into action after environmental 
calamity happened, that is, after the event. With the reasoning tunnelled towards preparing civilians for catastrophe - the threat of losing land, homes, livelihood, and lives - there was little scope to see that counteracting climate change was possible. If anything, it was impossible to hold back the sea. Therefore, mitigation and disaster reduction effectively meant accepting that the end was nigh because the big tragedy that might destroy us all could come at any time.

\section{In Kolonga}

While Tongan bureaucrats took their cue from regional and international organisations on what to believe about their country's fateful climate condition, rural villages reviewed their prospects from lived experience (Mcelroy, 2013). Parliamentary visits of peoples' representatives to electorates conveyed that the public who attended were not migrating overseas. Here were die-hard loyalists determined to stay in the homeland, and staying put, especially in rural settlements with small populations of kinfolk and clans, necessitated an alternative outlook on everyday life compared to the politics and policies enacted from above.

Ordinary people in the village were not drowning. They were fighting against the Tongan state assuming the system had the authority to uproot citizens from ancestral lands, reefs, lagoons, and access points to the open sea (Mission Blue, 2013). Relocation was a dangerous word. It meant removal, the last option when all else failed and "the hungry tide" (Zubrycki, 2011) had conquered the landscape. But most of all, relocation was not on the agenda to be discussed at parliamentary visits and village meetings because no citizen desired to be forcibly removed from their small, humble place of belonging in the expansive ocean-scape.

Kolonga is the village where my father was born in 1947, located in the eastern district of the main island Tongatapu (Brown Pulu, 2013). Currently, the population stands at 
1,167 according to the Tonga Department of Statistics 2011 preliminary count. Lord Nuku, the noble and estate-holder of Kolonga and noble's representative for 'Eua Island gave a higher estimate claiming 2,000 was closer to the mark. Whichever approximation it was, out of 518 registered voters from Kolonga, ten turned up for the parliamentary visit of Semisi Tapueluelu, the people's representative for Tongatapu.

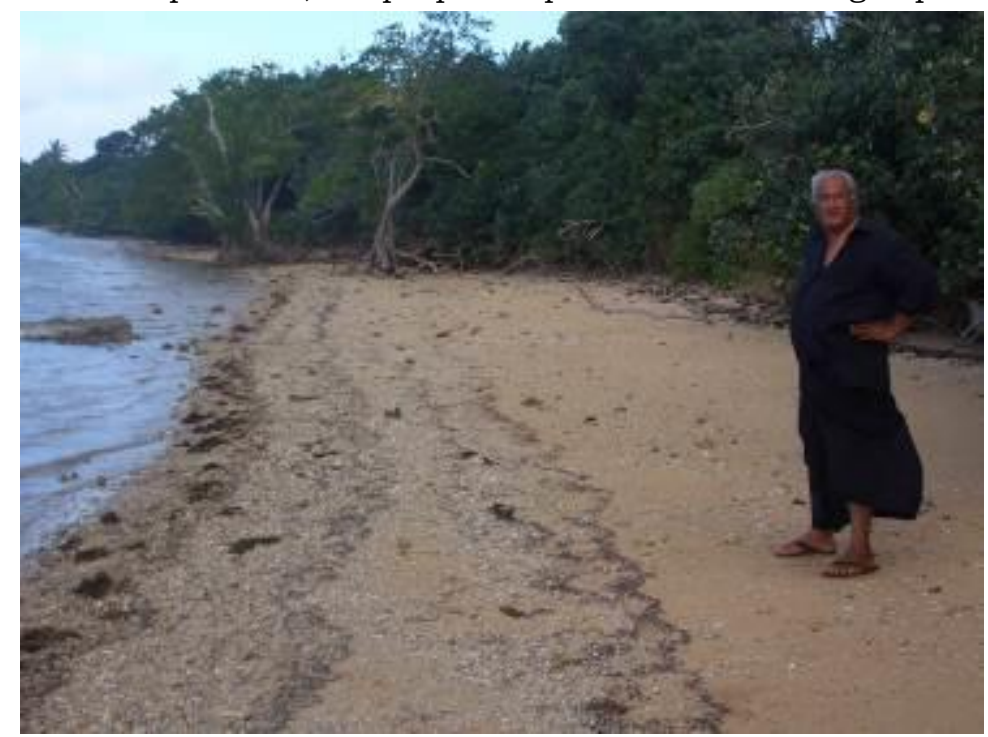

Lord Nuku, noble and estate-holder of Kolonga in the eastern district of Tonga standing on the village foreshore which exhibits exposure to sea level rise and environmental degradation.

Reflective of rural villages on nobles' estates, which were somewhat different to settlements on government land, kinship and clan relationships as well as loyalty to the estateholder were customary and socially expected in Kolonga. People were focused on livelihood and making a living in their territory, which comprised of plantation allotments allocated to families and for fishermen, the sea. A pastoral community with a history of cash cropping for the export market, small- 
scale farmers were accustomed to working together and trading as a village collective. Understandably, the development urgency was agricultural trade (Maddocks, 2013; Wiseman, 2013).

From the floor, an old farmer evoked the past. Remembering Tonga's golden era when the government commodities board bought produce directly from farmers, he intimated around state regulation of trade. In his time, this provided a safety measure that guaranteed fairer redistribution of employment and income-generating opportunities, especially for vulnerable groups like village youth. Importantly, it cut out middle-men from making unregulated profit from village growers and monopolising export agreements with overseas importers.

I would like to see the reestablishment of the commodities board. I don't know why it was disowned. I'm also concerned for the youth and the increase in offenses by youth due to unemployment. I grew up and follow my father in growing the copra and banana for export. I witness the positive effect of the board. I wish that government could resolve this issue so that Tonga could live in harmony. (Kolonga Resident 1 cited in Television Tonga News, 2013c).

Woven alongside the old farmer's appeal for government support for export trade were the village fishermen.

In another issue some of the fishermen asked for government assistance for their fishing boats which was provided previously, but has now been on hold since 2010. (Kolonga Resident 2 cited in Television Tonga News, 2013c).

Again, past government activity was remembered as better than the present relationship between rural communities and 
the state. Farmers and fishermen intersected on one point; the state had abandoned agriculture and fisheries trade when it was still the basic livelihood of ordinary people.

Asked by one audience member if the Government of Tonga could provide rudimentary infrastructure in the township - roads and streetlights - people's representative Semisi Tapueluelu spoke about Kolonga's inclusion in a "1.2 million pa'anga project." The Ministry of Environment and Climate Change was building a foreshore financed by Climate Investment Funds, and contracted out to New Zealand engineers for the project design (Climate Investment Funds, 2012, 2013). Local Tongan engineers were not employed to draw up plans, nor were they invited to work alongside the New Zealand consultants to develop industry skills.

In the meeting Mr Tapueluelu clarified that Kolonga is included in the 1.2 million pa'anga project of the Ministry of Environment for the construction of a foreshore from Nukuleka to Kolonga. (Television Tonga News, 2013c).

Clearly the people's representative for Tongatapu 10 had missed the boat. It was obvious he thought the foreshore restoration project priced at "1.2 million pa'anga" of Climate Investment Funds was the community development priority for his constituency. But was it, really? This was a top-heavy, state driven, multi-million pa'anga exercise paid for by a multilateral funding agency made up of the United Nations, international banks, and private sector investors. Oddly, it had botched at involving the people. By this, the Ministry of Environment and Climate Change project did not automatically secure the buy-in of villages. 


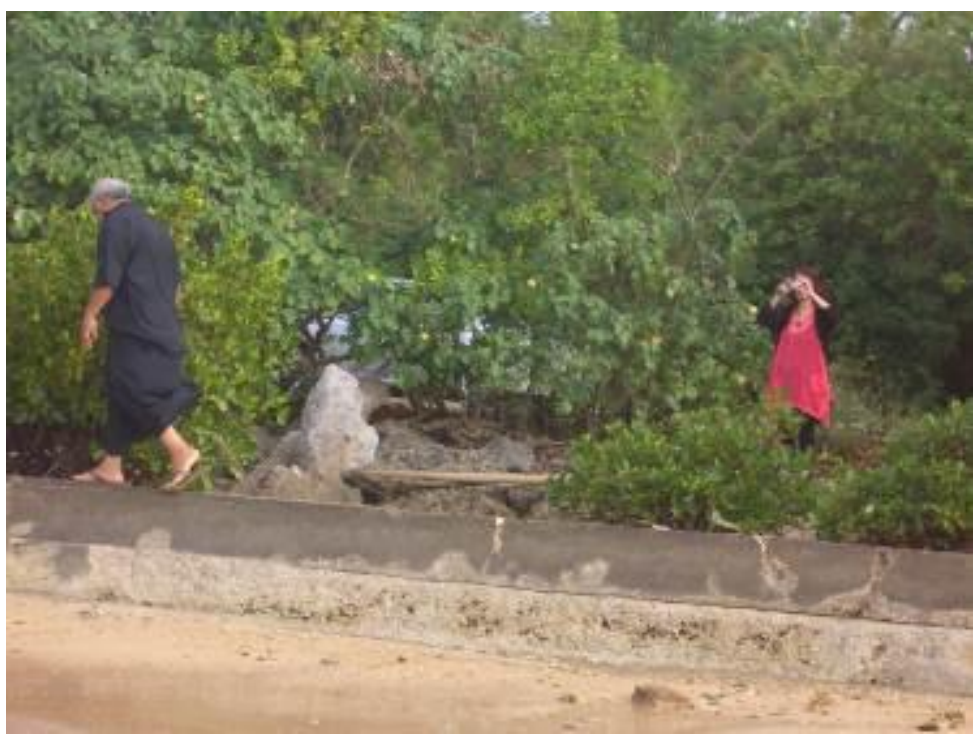

Lord Nuku, the noble and estate-holder of Kolonga in Tonga walking the seawall fronting his village foreshore with the author, Teena Brown Pulu, photographing the coastal erosion.

Among Kolonga people there was talk that government consultation and information on what was getting done, and who was doing it, had not taken place in a way that satisfactorily answered questions and concerns, or at the very least sought "free, prior, and informed consent" of community stakeholders in conjunction with "indigenous peoples' participation rights within international law" (Ward, 2011). There were two workshops on the project's design and operation in mid-year of 2013. Both were shut-off to the public, and only the first was reported in Tongan and New Zealand media as an affair between Tonga's Ministry of Environment and Climate Change, the Asian Development Bank, and the United Nations Strategic Program for Climate Resistance (SPCR) along with its contractors, New Zealand and 
Australian consultants (Matangi Tonga, 2013a; Spasifik Magazine, 2013).

Inviting non-government organisations to the first event in May 2013 was intended to represent community interests; not that it did, and not that any government bureaucrat identified this as the product of systematic divide-and-rule, which the Tongan state had failed to undo and resolve. For rural settlements placed under the authority of the government's project, nothing felt more humiliating than having the state and outsiders from foreign countries make decisions about a foreshore territory that kinfolk belong to, and have used for generations, without village approval. To learn of the rulings made over a communal living environment from media reports, added insult to wounded village pride.

Strengthening state level policy on climate adaptation had a contrary effect in respect of what it set out to do. The rift between communities and the state had been aggravated not alleviated, consolidating government authority over two factors defining and confining how community consultation was practiced in Tonga. At the outset, not only did the Government of Tonga call community consultation, but the state also decided the issues of public importance to be consulted on. There was no equaliser in which villages could petition the state to confer with them on matters which they considered of great consequence. Subsequent to this, the government developed a dependency problem: It relied on multilateral financing to implement climate adaptation, which amplified the accountability gap (Australian Government, 2013; Climate Investment Funds, 2013). The Government of Tonga was truly more answerable and responsible to international donor and investment agencies, than it was to their own village communities constituting the very country the project work was supposed to benefit (Black, 2013).

\section{Greening the blue}

In the South Seas, the regional gathering singled out for disturbing "the order of things" (Foucault, 1970) was the Fiji- 
led Pacific Islands Development Forum. Convened at the Sheraton Fiji Resort on Denarau Island from August 5th to the 7th, the Ministry of Foreign Affairs at the Fijian Government hosted the three-day talkfest for Pacific Island governments, businesses, and non-government organisations, with international donors alongside European and Asian governments observing the proceedings.

The Australian and New Zealand governments were apprehensive. They stood to lose the most, or so media outlets in their countries reported (Coutts, 2013a). No news commentary was convinced this was a straight-laced development forum. Instead, it became fixed in the "social imagination" as a political stratagem to contest and overthrow Australia and New Zealand's dominance in regional polity, trade, and leadership (Mills, 1959). Not that any high-ranking cabinet minister or senior government bureaucrat from Australia and New Zealand commented along these lines; their silence being interpreted as a response in itself.

Director of the University of Fiji's Centre for International and Regional Affairs, Richard Herr, exemplified that guesswork on what the Pacific Islands Development Forum was really about propelled the storyline. Herr's analysis was the conventional Pacific Islands Forum led by Australia and New Zealand had been "a thorn in the side of Fiji," obstructing Prime Minister Bainimarama from assuming the leadership of the Melanesian Spearhead Group in 2010. Founded as a counter-body, the Pacific Islands Development Forum adopted a different approach orienting its business in government collaboration with and all sectors, including not-for-profit organisations. At a glance, it could be seen as a move to prohibit Australia and New Zealand's political interference in sub-regional relations between Pacific Island states. But this was not to disregard the potential a new association had to be a more relevant interface between governments and communities, one reflecting island development priorities 
rather than Australia and New Zealand's policies and principles.

The reason why I think so much of the commentary has been that it's to replace the forum is that the forum clearly has been a thorn in the side of Fiji. It's been not a conciliatory regional agency but rather used to impose sanctions on Fiji. And indeed this meeting itself grew out of a situation when the Prime Minister Frank Bainimarama was meant to take over the reins of the MSG, the Melanesian Spearhead Group. That meeting was cancelled. As Fiji saw it, Australia and New Zealand interfered with the reins being handed over; there was tit-for-tat expulsion of heads of mission. And the arrangement was called the engaging with the Pacific meeting. And that turned out to be much broader, and this has emerged out of that. I guess you could say there are mixed signals there. They are at one level, a challenge to the forum, and at another level creating a different kind of structure, a parallel body that might be more authentic, more legitimate in expressing the development needs of the region. (Richard Herr cited in Coutts, 2013a).

Whichever way the long-running saga unravelled, clearly the Pacific Islands Development Forum had rewritten the script by performing a counter narrative with new actors in lead roles (Nanol, 2013). If there was a meeting of political will validating how Pacific Island governments, businesses, and non-government organisations distinguished their difference to, and independence from, Australia and New Zealand, then it was through the notion of greening the blue. That is, by conceptualising the world's largest ocean-scape and its diverse islands and peoples as an interconnected "green-blue Pacific economy." The opening address at the Pacific Islands Development Forum given by Fijian Prime Minister, Frank 
Bainimarama, emphasised that colour coding Pacific Island states as "green-blue" had branding power for marketing a region of "one ocean, one people" to the outside world (The Jet, 2013).

We are one ocean, one people, seeking common solutions. And so today we join hands with each other and with our development partners from outside the region to strive for a Green-Blue Pacific economy. (Prime Minister of Fiji cited in The Jet, 2013).

Philippine academic of sustainable environments, Cora Claudio, traced the movement of greening the blue to a political act by "Pacific Small Island Developing States (Pacific SIDS) to gain momentum "on the way to Rio+20," the United Nations Conference on Sustainable Development in Rio De Janeiro, Brazil from the 20th to the 22nd of June 2012. The author saw the build-up to Rio+20 as an origin moment in which Pacific Island states "started promoting 'Blue Economy,' which is focused on the marine environment. "For the Pacific SIDS," Claudio recounted, "green economy is a blue economy that prominently features oceans, which account for almost 71 percent of the earth's surface" (Claudio, 2013).

Significantly, Claudio noted the economy versus environment dichotomy that surfaced in the two-coloured labelling of Pacific green-blue economies.

Some concerns of the Pacific SIDS are increasing their share of benefits from the use of their marine living resources and building the resilience of marine ecosystems to the impact of climate change and ocean acidification. (Claudio, 2013).

A blue-green balancing act centred on how to use natural resources from the ocean for commercial profit, namely fish and seabed minerals, while concurrently protecting the 
environment from further human ruin beyond repair (Garrett, 2013a, 2013b; Lipset, 2013; Robertson, 2013). Speaking to the "2013 Global Eco-Forum for Building an Eco-Civilization: Green Transformation and Transition" (CCTV, 2013) hosted by the People's Republic of China in Guiyang, the Prime Minister of Tonga, Lord Tu'ivakano, advocated the blue-green trademark.

For us, if you like, in the ocean-locked small island countries like Tonga, our environment is dominated by the sea. So if we are talking color coded revolution, our experience may be more appropriately called a blue revolution, one based in the responsible extraction of value from the sea and the responsible custody of that very vital resource. The green-blue paradigm in fact completes the picture, for it now takes into account the need to include the ocean and the sea in any discussion about eco-civilisation and eco-innovation. (Prime Minister of Tonga cited in Tonga Government Portal, 2013b).

By a similar communication style to the Prime Minister of Fiji, the Tongan Premier plugged for oceanic resources as the customary economy of Pacific Island states (Tonga Government Portal, 2013b, 2013c). The speech got tangled when the conflicting terms "responsible extraction" and "responsible custody" were lined up side-by-side suggesting that a development formula for reconciling commercialism and conservation existed in practice (Tonga Government Portal, 2013b). Former Papua New Guinea Prime Minister, Makere Morauta, set the record straight. In reality, there was none. The truth was Pacific Island states had not manufactured a remedy for integrating the "modernity" of a hyper-capitalist economy into small, insular, kin-based societies. Concomitantly, in the face of rapid modernisation, how does the South Pacific hold "true to its deep-rooted social and 
cultural values?" (Morauta, 2013). "Regionalism has lost its political direction," Morauta stated, not mixing his words because he could. He was no longer sitting in the prime minister's hot seat where his words, opinions, and delivery were put under the microscope of the media and academia.

How the region deals with modernity - including its many socially, economically and politically challenging facets - while holding true to its deep-rooted social and cultural values is not yet resolved. Yet we hear loudly from citizens and politicians alike that the right political conversations are not being had about these things. That the region is stumbling into the future, rather than confidently striding forwards certain of where it wants to go. Citizens voices, we were told time and time again, are not being heard by the political elite. In short, regionalism has lost its political direction. (Morauta, 2013).

\section{Counter narratives}

Solomon Islands academic, Tarcisius Tara Kabutaulaka, delivered the 2012 plenary at the 9th Conference of the European Society for Oceanists (ESfO) hosted by the University of Bergen in Norway. His paper titled, Stories and Power in Oceania, addressed storytelling as speech acts of social control (Kabutaulaka, 2012b). Controlling the narrative and its retelling, Kabutaulaka commented, was a politicised technique framing the manner that governments, nationstates, societies, and peoples are predominantly represented in the public domain. 


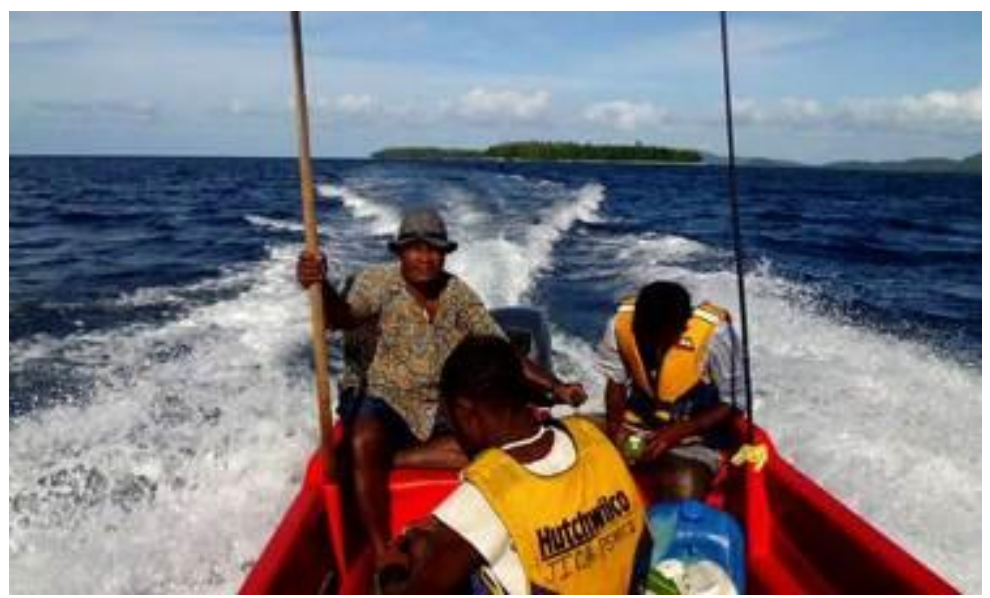

Tarcisius Kabutaulaka navigating his way to the capital of Honiara from his homeland on the Weather Coast of Guadalcanal in the Solomon Islands (Photograph: Kabutaulaka, 2012).

Academic researchers, perhaps more so than politicians, are highly prized storytellers afforded status and respect for their knowledge and viewpoints in any given society (Back, 2013; Chambers, 2005). But none-so-much as the small islands of the world's largest ocean where one's scholarly work counts, in many ways, as cultural capital. By this, I mean that intellectual writing is often read as a representation of one's own kinfolk, clan, and countrymen and women. Whether it really is or not is seldom debated because for small society peoples connected by vast ocean, one's people and place of belonging is fundamental to validating that this work, my writing, these words and ideas are real, authentic, a true story. It therefore feels right for me to close the essay with the voice of a Melanesian scholar because a sizeable amount of angst surfacing from Australia and New Zealand's regional relations has culminated from Melanesian leadership on the South Pacific front (Kabutaulaka, 2012a, 2012b). 
Without a doubt, regional polity in the 21 st century South Pacific is different to the 2oth. Branded as the Asian century, China's economic and diplomatic presence in Pacific Island states has troubled Australia and New Zealand, two settler colonies and developed countries bordering the island states that have often taken for granted their countries historical and privileged position of supremacy over regional trade, politics, and leadership (China Daily, 2013; Pickford, 2013; Radio New Zealand, 2013b). The Australian and New Zealand governments do recognise the region is rapidly changing. But the real trouble they encounter is the limits of their own experiential knowledge in genuinely listening, without assuming they know what is best for Pacific Island states, and negotiating along conciliatory terms (Said, 1978).

In the postcolonial present, Pacific Island states share a political aversion to being subjugated by a power imbalance of dominance and subservience, the kind of paternalistic relationship associated with the colonial past. What I am saying is that Australian and New Zealand politicians and bureaucrats as a collective have marginal proficiency in how to engage with Pacific Islanders who are not happy, smiling, friendly Natives on cue and may no longer want to be their loyal, unquestioning, and obedient followers.

The twist is that the 21 st century South Pacific could transform into the Melanesian century given that this subregion has the largest landmass, natural resource wealth, and population (Regenvanu, 2013). Regionally, Pacific Island states are navigating towards a contrasting future compared to 2oth century history in which independent Melanesian states were framed by white academics as "hot spots" (State, Society and Governance in Melanesia, 2011). Such labelling inferred that the Melanesian sub-region was unstable and susceptible to armed conflict, civil uprising, and weak states.

How have representations of Melanesia altered today? I am not inquiring about the "social imagination" of outsider academics, politicians and media in etching out white people's 
tales of black people in Melanesia (Mills, 1959). But for the indigenous peoples of Melanesian states, what are their thoughts on the leadership role their sub-region might assume in remodelling regional polity for Pacific Island states?

If there is a political swell in the South Pacific for bottomup regional polity allowing decision-making power to the masses, to the ordinary people, then Pacific Islander academics are doubly accountable (Marcellin, 2013; Powell, 2013). In the first vein because of blood ties to kinfolk and an origin place, there is an inherited social responsibility to the communities we research, write about, lay claim to as our people, and who acknowledge us as one of their own. An insider's position, however, is also intellectual prowess in the research industry granting expertise that researchers of our homelands who are not Pacific Islanders envy, covet, and have difficulty dismantling and ignoring.

In the very industry Pacific Islander academics make a living from - the university system - a consciousness develops in which it becomes standard practice to scrutinise dominant narratives created by others about our kind; if anything, so the others know that "stories are central to power" and we are about the business of documenting the counter narrative (Kabutaulaka, 2012b, p. 3). On this note, the final word belongs to Tarcisius Tara Kabutaulaka from the Weather Coast of Guadalcanal in the Solomon Islands.

You see, stories are central to power and as a means of controlling society. It is no secret that if one controls the narrative, then one could control knowledge about and representations of societies, cultures and peoples. It is because of this that some governments (and others in positions of power) often want to control stories that are told about them and those of the societies they rule. But, also important are the story tellers, the audiences, where stories are told, and the 
purposes for which they are told. (Kabutaulaka, 2012b, p. 3). 


\section{References}

Australian Government. (2013). Pacific Adaptation Strategy Assistance Programme. Australian Government, Department of Industry, Innovation, Climate Change, Science, Research and Tertiary Education, Canberra, Australia, August 9. Retrieved from

http://www.climatechange.gov.au/climate-change/grants/pacificadaptation-strategy-assistance-program

Back, L. (2013). The value of academic writing in its ability to channel further thought. Impact of Social Sciences: Maximising the Impact of Academic Research, The London School of Economics and Political Science, United Kingdom, June 28. Retrieved from

http://blogs.lse.ac.uk/impactofsocialsciences/2013/06/28/thevalue-of-academic-writing/

Bedford, R. and Bedford, C. (2010). International Migration and Climate Change: A Post Copenhagen Perspective on Options for Kiribati and Tuvalu. In Climate Change and Migration: South Pacific Perspectives, edited by Bruce Burson. Wellington, New Zealand: Institute of Policy Studies, Victoria University, Pp. 89134.

Black, G. (2013). Your Clothes Were Made by a Bangladeshi Climate Refugee. Mother Jones: Environment, San Francisco, USA, July 30. Retrieved from

http://www.motherjones.com/environment/2013/07/bangladeshgarment-workers-climate-change

Bodansky, D. (2009). Legal Form of a New Climate Agreement: Avenues and Options. Pew Center on Global Climate Change, Philadelphia and Washington DC, Pp. 1-8.

Brown Pulu, T. (2013). This lazy Native's quitting the daytime job. Going home to the village. Yeah right. In Pacific Identities and Wellbeing: Cross-Cultural Perspectives, edited by M. Agee, T. McIntosh, P. Culbertson, and C. Makasiale. Dunedin, New Zealand: University of Otago Press, Pp. 84-102.

CCTV. (2013). 2013 Eco-Forum Global kicks off in Guiyang. China Central Television: English, Beijing, People's Republic of China, July 20. Retrieved from

http://english.cntv.cn/program/newsupdate/20130720/102014.sht $\underline{\mathrm{ml}}$

Chambers, R. (2005). Ideas for Development. London, United Kingdom: Earthscan.

China Daily. (2013). Commentary: New Zealand needs to start building trust in the long term. China Daily, Beijing, People's Republic of China, August 5. Retrieved from

http:/ / www.chinadaily.com.cn/xinhua/2013-0805/content_9769307.html

Chung, T. (2013). Rising Ocean, Changing Lives: Adapting to Climate Change on Lifuka Island, Tonga. Secretariat of the Pacific Community Regional Media Centre, Suva, Fiji, January. Retrieved from

http://vimeo.com/53200521 
Claudio, C. (2013). From Green to Blue Economy. Inquirer Business: Philippine Daily Inquirer, Makati City, Manila, Philippines, June 23. Retrieved from

http:// business.inquirer.net/ 128587 /from-green-to-blue-economy

Climate Investment Funds. (2012). Strategic Program for Climate Resistance for the Kingdom of Tonga. Climate Investment Funds (CIF), Washington DC, USA, April 30, Pp. 1-210.

Climate Investment Funds. (2013). Tonga. Climate Investment Funds (CIF), Washington DC, USA, August 13. Retrieved from

https://www.climateinvestmentfunds.org/cifnet/?q=country/tonga

Coutts, G. (2013a). PIDF planned to marginalise Pacific Islands Forum. Australian Broadcasting Commission: Radio Australia: Pacific Beat, Melbourne, Australia, August 6. Retrieved from

http://www.radioaustralia.net.au/international/radio/program/pacifi c-beat/pidf-planned-to-marginalise-pacific-islandsforum/1171616

Coutts, G. (2013b). Climate change carves 40 metres off edge of Tongan island. Australian Broadcasting Commission: Radio Australia: Pacific Beat, Melbourne, Australia, August 7. Retrieved from

http://www.radioaustralia.net.au/pacific/radio/program/pacificbeat/climate-change-carves-40-metres-off-edge-of-tonganisland $/ 1172292$ ?autoplay $=1172312$

Dawson, B. and Spannagle, M. (2009). The Complete Guide to Climate Change. New York: Routledge-Taylor and Francis Group.

De Mesquita, B. B. (2009). Recipe for Failure: Why Copenhagen will be a bust, and other prophecies from the foreign-policy world's leading predictioneer. Foreign Policy, Washington DC, USA, November/December. Retrieved from

http:/ / www.foreignpolicy.com/articles/2009/10/16/recipe_for_failure ?page $=0,0$

de Nazareth, M. (2009). Sinking Islands in the Pacific: 1.5 Degrees Celsius to Stay Alive. Counter Currents Organization, Kerala, India, December 15. Retrieved from

http://www.countercurrents.org/nazareth151209.htm

Doebbler, C. and Wewerinke, M. (2009). What happened in Copenhagen? Al-Ahram: Weekly Online, Cairo, Egypt, Issue No. 978, 24-30 December. Retrieved from

http://weekly.ahram.org.eg/2009/978/envrnmnt.htm

Fagan, B. (2013). The Impending Deluge. New York Times: The Opinion Pages, New York, USA, May 31. Retrieved from

http://www.nytimes.com/2013/06/01/opinion/global/brian-faganthe-impending-deluge.html?_r $\mathrm{r}=0$

Fisher, D. R. (2004). National Governance and the Global Climate Regime. Maryland, United States: Rowman and Littlefield Publishers, Incorporated.' 
Folau, L. (2013). UN rep challenges Pacific peoples to think long-term about disaster risks. Matangi Tonga Online, Nuku'alofa, Tonga, July 2. Retrieved from

http://matangitonga.to/2013/07/02/un-rep-challenges-pacificpeoples-think-long-term-about-disaster-risks

Foucault, M. (1970). The Order of Things: An Archaeology of the Human Sciences. London, United Kingdom: Tavistock Publications.

Garrett, J. (2013a). Pacific warned on risk of increased mining-related conflict. Australia Broadcasting Commission: Radio Australia: Pacific Beat, Melbourne, Australia, May 22. Retrieved from

http://www.radioaustralia.net.au/international/radio/program/pacifi c-beat/pacific-warned-on-risk-of-increased-miningrelatedconflict/1134610

Garrett, J. (2013b). Marshall Islands seeks support for climate change initiative. Australia Broadcasting Commission: Radio Australia: Pacific Beat, Melbourne, Australia, July 29. Retrieved from

http:/ / www.abc.net.au/news/2013-07-29/an-marshall-islands-callson-australia-to-tackle-climate-change/4851434

Gibson, D. (2010). Wansolwara: Pacific Island representation at COP15 climate conference criticised. Pacific Scoop: AUT's Pacific Media Centre, Auckland, New Zealand, June 30. Retrieved from

http://pacific.scoop.co.nz/2010/06/wansolwara-pacific-islandrepresentation-at-cop15-climate-change-conference-criticised/

Giddens, A. (2009). The Politics of Climate Change. Cambridge, United Kingdom: Polity Press.

Goldin, I. (2013). Divided Nations: Why Global Governance is Failing and What Can We Do About it? Oxford, United Kingdom: Oxford University Press.

Halapua, S. (2012). Indigenous Knowledge. Waves of Change: Climate Change in thePacific Islands and Implications for Hawai'i International Conference, April 4-6, The Center for Pacific Island Studies, University of Hawai'i at Manoa, Honolulu, USA, Retrieved from

http:/ / olelo.granicus.com/MediaPlayer.php?view_id=30\&clip_id=3487 $\underline{4}$

Held, D. and Hervey, A. F. (2009). Democracy, Climate Change and Global Governance. Policy Network Paper, London, United Kingdom, Pp. 1-20.

Hill, B. (2013). Call for a joint Pacific/Australia/NZ labour market strategy. Australia Broadcasting Commission: Radio Australia: Pacific Beat, Melbourne, Australia, July 2. Retrieved from

http://www.radioaustralia.net.au/pacific/radio/program/pacificbeat/call-for-a-joint-pacificaustralianz-labour-marketstrategy/1155180?autoplay=1155122

Hulme, M. (2009). Why We Disagree About Climate Change: Understanding Controversy, Inaction, and Opportunity. Cambridge, United Kingdom: Cambridge University Press. 
Idso, C. D., Carter, R. M. and Singer, S. F. (Eds.) (2011). Climate Change Reconsidered: 2011 Interim Report of the Nongovernmental Panel on Climate Change (NIPCC). Chicago, Illinois, USA: The Heartland Institute.

Islands Business. (2013). Tonga integrates climate change and disaster risk management into education. Islands Business, Suva, Fiji, July 10. Retrieved from

http:/ / www.islandsbusiness.com/news/fiji/1849/tonga-integratescc-and-drm-into-education/

Kabutaulaka, T. (2012a). Tough struggle for people of Tasimauri to win their deserved hospitality. Pacific Media Centre: Te Amokura, Auckland, New Zealand, June 29. Retrieved from

http://www.pmc.aut.ac.nz/articles/tough-struggle-people-tasimauriwin-their-deserved-hospital

Kabutaulaka, T. (2012b). Stories and Power in Oceania. Keynote Address to the $9^{\text {th }}$ Conference of the European Society for Oceanists (ESfO), University of Bergen, Norway, December 5-8, Pp. 1-15.

Kaniva Pacific. (2013). Bills for Tongans to elect the Prime Minister and nobles. Kaniva Pacific, Auckland, New Zealand, July 9. Retrieved from

http://www.nzkanivapacific.co.nz/2013/07/bills-for-tongans-to-electthe-prime-minister-and-nobles/\#.Uf4X7mmN3IU

Komai, M. (2013a). Cook Islands, Tonga and Vanuatu share practical experiences on CC and DRM integration. Pacific Islands News Association (PINA), Suva, Fiji, July 9. Reposted in Tonga Broadcasting Commission, Nuku'alofa, Tonga, July 9. Retrieved from

http://www.tonga-broadcasting.net/cook-islands-tonga-and-vanuatushare-practical-experiences-on-cc-and-drm-integration-bymakereta-komai-pacnewshttpwwwpinacomfjindexphpppacnewsmpacnews.html

Komai, M. (2013b). Climate change and disasters, the Pacific's biggest sustainable development challenges. Pacific Islands News Association (PINA), Suva, Fiji, July 9. Retrieved from

http: / / www.pina.com.fj/?p=pacnews\&m $=$ read\&o $=88415893551 \mathrm{db} 434$ ce4a0b52141f5c

Lipset, D. (2013). The New State of Nature: Rising Sea-Levels, Climate Justice, and Community-based adaptation in Papua New Guinea (2003-2011). Conservation and Society, 11 (2): 144-157.

Lord Ma'afu. (2009). Sinking Islands, The Pacific Voice: 1.5 to Stay Alive. United Nations Climate Change Conference, Copenhagen, Denmark, December 15. Retrieved from

http://webcast.cop15.dk/kongresse/cop15/templ/play.php?id_kongr esssession $=2583 \&$ theme $=$ cop 15

Maddocks, T. (2013). Solomon Islands farmers practice new methods. Australian Broadcasting Commission: Radio Australia: Pacific Beat, Melbourne, Australia, June 28. Retrieved from 
http://www.radioaustralia.net.au/pacific/radio/program/pacific-

beat/solomon-islands-farmers-practice-newmethods / 1153438?autoplay $=1153500$

Marcellin, A. (2013). Moratorium on Research in Vanuatu. Vanuatu National Cultural Council, Port Vila, Vanuatu, June 27. Retrieved from

http://vanuatuculturalcentre.vu/wpcontent/uploads/2013/03/Moratorium-on-Research-1.pdf

Marcus, G. E. (1980). Role Distance in Conversations Between Nobles and Their "People." The Journal of Polynesian Society, 89 (4): 435453.

Maron, N. and Connell, J. (2008). Back to Nukunuku: Employment, identity and return migration in Tonga. Asia Pacific Viewpoint, 49 (2): 168-184.

Matangi Tonga. (2013a). Tonga to increase resilience to climate change. Matangi Tonga, Nuku'alofa, Tonga, May 15. Retrieved from

http://matangitonga.to/2013/05/15/tonga-increase-resilienceclimate-change

Matangi Tonga. (2013b). Tonga's biggest budget relies on donor pledges. Matangi Tonga, Nuku'alofa, Tonga, June 12. Reposted in Islands Business, Suva, Fiji, June 12. Retrieved from

http://www.islandsbusiness.com/news/tonga/1464/tongas-biggestbudget-depends-on-donor-pledges/

Mcelroy, A. (2013). 'Like our ancestors, if we have heart, we can do it.' The United Nations Office for Disaster Risk Management, Geneva, Switzerland, July 9. Retrieved from

http://www.unisdr.org/archive/33894

Mills, C. W. (1959). The Sociological Imagination. London, United Kingdom: Oxford University Press.

Mission Blue. (2013). Pacific Warriors: We're not drowning. We are fighting. Mission Blue: Sylvia Earle Alliance, USA, March 11. Retrieved from

http:/ / mission-blue.org/2013/03/pacific-warriors-were-notdrowning-we-are-fighting/

Morauta, M. (2013). Review Chair's Remarks: Pacific Plan Action Committee Meeting. Pacific Plan Review 2013: Pacific Islands Forum Secretariat, Suva, Fiji, August 6. Retrieved from

http://www.pacificplanreview.org/media/press-statements/

Nanol, F. (2013). PNG in luke warm support of PIDF. Australian Broadcasting Commission: Radio Australia: Pacific Beat, Melbourne, Australia, August 12. Retrieved from

http://www.radioaustralia.net.au/international/radio/program/pacifi c-beat/png-luke-warm-in-support-of-

pidf/1174344?autoplay $=1174300$

Pacific Plan Review. (2013). Pacific Plan Review 2013, Suva, Fiji, August 11. Retrieved from

http://www.pacificplanreview.org/pacific-plan/ 
Paton, K. (2009). At Home or Abroad: Tuvaluans Shaping a Tuvaluan Future. Unpublished Master of Development Studies Thesis, Victoria University of Wellington, Wellington, New Zealand, Pp. 1174.

Perrottet, A. (2013). Ministers meeting in Fiji say work to be done on aid funds. Radio New Zealand International: Pacific News Service, Auckland, New Zealand, July 11. Retrieved from

http://www.rnzi.com/pages/news.php?op=read\&id=77492

Pickford, J. (2013). Why are the Chinese interested in Tonga? $B B C$ News, Ha'apai, Tonga, July 27. Retrieved from

http://www.bbc.co.uk/news/magazine-23469223

Powell, K. (2013). Voting Rights, Affirmative Action, and the Slow Murder of Dr. King's 'Dream.' Daily Kos: News, Community, Action, Washington DC, USA, June 26. Retrieved from

http://www.dailykos.com/story/2013/06/26/1219055/-Voting-

Rights-Affirmative-Action-and-the-Slow-Murder-of-Dr-King-sDream?showAll=yes\#

Radio New Zealand. (2013a). SPC to cooperate with IUCN. Radio New Zealand International: Pacific News Service, Auckland, New Zealand, June 25. Retrieved from

http://www.rnzi.com/pages / news.php?op=read\&id $=77073$

Radio New Zealand. (2013b). Chinese aircraft in Tonga to fly next week. Radio New Zealand International: Pacific News Service, Auckland, New Zealand, July 26. Retrieved from

http://www.rnzi.com/pages / news.php?op=read\&id=77852

Regenvanu, R. (2013). Opening Address by the Honourable Ralph Regenvanu, Minister for Lands, Government of the Republic of Vanuatu. Pacific ACP States Regional Training Workshop on Social Impacts of Deep Sea Mining Activities and Stakeholder Participation, June 10-14, Holiday Inn, Port Vila, Vanuatu. Retrieved from

http:/ / pang.org.fj/99-per-cent-offshore-mining/

Robertson, H. (2013). Tonga's renewable energy push. Petroleum Economist: The Authority on Energy, London, United Kingdom, July 1. Reposted on Tonga NZ Net, Auckland, New Zealand, July 2. Retrieved from

http://www.tonganz.net/home/tongas-renewable-energy-push/

Robie, D. (1997). Fri Press: Media Freedom in the Pacific, University of Papua New Guinea and the Australian Centre for Independent Journalism. Retrieved from

http://www.youtube.com/watch?v=MKcRTL9yEV8

Said, E. W. (1978). Orientalism. London, United Kingdom: Routledge and Kegan Paul.

Spasifik Magazine. (2011). Tonga has a high level of vulnerability to climate hazards. Spasifik Magazine, Auckland, New Zealand, May. Retrieved from

http://spasifikmag.com/environment/resilienseclimate/ 
State, Society and Governance in Melanesia. (2011). State, Society and Governance in Melanesia Program. Development Policy Centre, Australian National University, Canberra, Australia, May 2. Retrieved from

http://devpolicy.org/state-society-and-governance-in-melanesia/

Television Tonga News. (2013a). Television Tonga News in English, Tonga Broadcasting Commission, Nuku'alofa, Tonga, July 10. Retrieved from

http:/ / www.youtube.com/watch?v=U6yUmaIFW6I

Television Tonga News. (2013b). Television Tonga News in English, Tonga Broadcasting Commission, Nuku'alofa, Tonga, July 15. Retrieved from

http://www.youtube.com/watch?v=hAfo6kYrleY

Television Tonga News. (2013c). Television Tonga News in English, Tonga Broadcasting Commission, Nuku'alofa, Tonga, July 21. Retrieved from

http://www.youtube.com/watch?v=pgKu45xglJc

Television Tonga News. (2013d). Television Tonga News in English, Tonga Broadcasting Commission, Nuku'alofa, Tonga, August 2. Retrieved from

http: / / www.youtube.com / watch?v=t6T9X8dElzE\&feature=c4overview\&list=UUJsR-wS1oz5i-OhNUsWU_9w

The Fijian Government. (2013). Keynote Address by His Excellency The Prime Minister of the Democratic Republic of Timor-Leste Kay Rala Xanana Gusmao. The Fijian Government, Suva, Fiji, August 5. Retrieved from

http:/ / www.fiji.gov.fj/Media-Center/Speeches/KEYNOTE-ADDRESSBY-HIS-EXCELLENCY-THE-PRIME-MINIST.aspx

The Jet. (2013). PM Bainimarama Address at the Inaugural Pacific Islands Development Forum (PIDF) Meeting. The Jet: Fiji's First Community Newspaper, Suva, Fiji, August 5. Retrieved from

http://thejetnewspaper.com/2013/08/05/pm-bainimarama-addressat-the-inaugural-pacific-islands-development-forum-pidf-meeting/

Tonga Government Portal. (2013a). Special Representative of UNSG for Disaster Risk Reduction visits Tonga. Tonga Government Portal: Ministry of Information and Communications, Nuku'alofa, Tonga, July 3. Retrieved from

http:/ / www.mic.gov.to/news-today/press-releases/4495-specialrepresentative-of-unsg-for-disaster-risk-reduction-visits-tonga

Tonga Government Portal. (2013b). Global Forum (China): Prime Minister's Speech on Building Eco-Civilization. Ministry of Information and Communications, Government of Tonga, Nuku'alofa, Tonga, July 20. Retrieved from

http:/ / www.mic.gov.to/news-today/press-releases/4521-lord-primeministers-speech-on-the-theme-building-eco-civilization-guiyangpeoples-republic-of-china

Tonga Government Portal. (2013c). Tonga at the inauguration of (PIDF) Pacific Islands Development Forum. Ministry of Information and 
Communications, Government of Tonga, Nuku'alofa, Tonga, August 9. Retrieved from

http://www.mic.gov.to/news-today/press-releases/4563-tonga-atthe-pidf-inaugural-meeting-leadership-and-partnership-for-greenblue-economies

Uludong, N. (2013). Threatened small islands call for "concrete" climate action. Thomson Reuters Foundation, Nairobi, Kenya, April 29. Retrieved from

http://www.trust.org/item/20130429150352mp45i/?source=hpeditorial

Ward, T. (2011). The Right to Free, Prior, and Informed Consent: Indigenous Peoples' Participation within International Law. Northwestern Journal of International Human Rights, 10 (2): 54-84.

Wiseman, D. (2013). Full organic certification sought for Tonga's Ha'apai. Radio New Zealand International: Pacific News Service, Auckland, New Zealand, June 26. Retrieved from

http://www.rnzi.com/pages/news.php?op=read\&id=77104

Zubrycki, T. (2011). The Hungry Tide: A personal story about a Pacific nation on the frontline of climate change. Tom Zubrycki Productions, Melbourne, Australia.

\section{Photographs}

Kolonga, Kingdom of Tonga, Teena Brown Pulu, July 2013

Sinking Islands Press Conference, The Guardian, December 2009

Kolonga, Kingdom of Tonga, Richard Bedford, July 2013

Nukunuku, Kingdom of Tonga, Melino Maka, June 2011

Kolonga, Kingdom of Tonga, Richard Bedford, July 2013

Kolonga, Kingdom of Tonga, Richard Bedford, July 2013

Weather Coast, Solomon Islands, Tarcisius Kabutaulaka, June 2012 